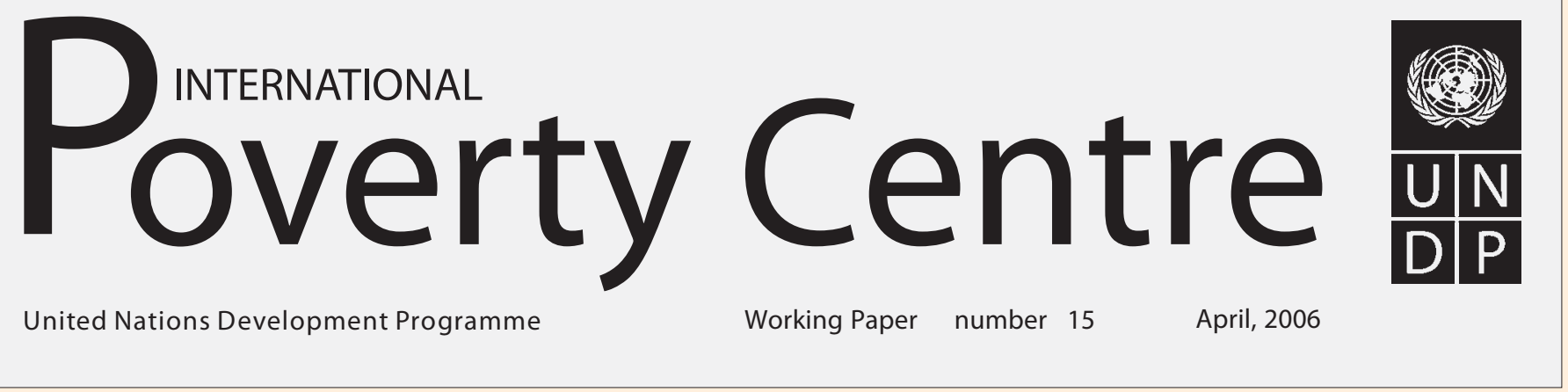

\title{
ASSESSING THE PRO-POORNESS OF GOVERNMENT FISCAL POLICY \\ IN THAILAND
}

Hyun H. Son

International Poverty Centre,

United Nations Development Programme 


\title{
Copyright $\odot 2006$
}

United Nations Development Programme International Poverty Centre

\author{
International Poverty Centre \\ SBS - Ed. BNDES, $10^{\circ}$ andar \\ 70076900 Brasilia DF \\ Brazil
}

povertycentre@undp-povertycentre.org

www.undp.org/povertycentre

Telephone +55 6121055000

Fax +556121055001

\section{Rights and Permissions}

All rights reserved.

The text and data in this publication may be reproduced as long as the source is cited.

Reproductions for commercial purposes are forbidden.

The International Poverty Centre's Working Papers disseminates the findings of work in progress to encourage the exchange of ideas about development issues. Our main objective is to disseminate findings quickly, so we compromise and bear with presentations that are not fully polished. The papers are signed by the authors and should be cited and referred to accordingly. The findings, interpretations, and conclusions expressed in this paper are entirely those of the authors. They do not necessarily represent the view of the International Poverty Centre or the United Nations Development Programme, its Administrator, Directors, or the countries they represent.

Working Papers are available online at http://www.undp.org/povertycentre and subscriptions might be requested by email to povertycentre@undp-povertycentre.org 


\title{
ASSESSING THE PRO-POORNESS OF GOVERNMENT FISCAL POLICY IN THAILAND
}

\author{
Hyun H. Son*
}

\begin{abstract}
This paper proposes a methodology to assess the pro-poorness of government fiscal policies in view of bringing marginal reforms. A government policy is said to be pro-poor if it benefits the poor proportionally more than the non-poor. The author first derives the poverty elasticity for the general class of poverty. Then, using the idea of poverty elasticity, she proposes a propoor index that can be utilized to assess government expenditure and tax policies. This index may be useful in making the government fiscal system more beneficial towards the poor through marginal reforms. The proposed methodology is applied to Thailand, utilizing the 1998 Socio-Economic Survey.
\end{abstract}

Keywords: Poverty, Income distribution, Pro-Poor, Tax policy, Public spending.

JEL Classification: I3, D31, H2, H3

* I am grateful to Professor Nanak Kakwani for his valuable comments and suggestions.

E-mail address for correspondence: hyun.son@undp-povertycentre.org; Tel: 55-61-2105 5025; Fax: 55-61-2105 5000/5001. 


\section{INTRODUCTION}

Fiscal policy represents one of the key instruments by which public actions can have impact on poverty. This can happen both through its impacts on growth and on distribution. Fiscal policy is one of a number of important influences on growth rates, and given other things, a sustained higher growth rate will translate into faster poverty reduction (Gemmell 2001, McKay 2002). However, fiscal policy is also one of the main mechanisms by which policy causes an impact on distribution. It can achieve this by means of static redistribution, depending upon the patterns of government spending and revenue raising, or through dynamic redistribution--through its influence on the distributional pattern of growth (Killick 2002). Indeed fiscal policy is likely to play a central role in generating a pro-poor pattern of growth, which benefits the poor proportionally more than the non-poor (Kakwani and Son 2004). Other things being equal, pro-poor growth will be much more effective at reducing poverty. Unfortunately, all too little is known about the precise role of fiscal policy in achieving pro-poor growth.

This paper is concerned with the assessment of the impact of fiscal policy on poverty. In this context, this paper proposes a methodology to assess the pro-poorness of government fiscal policies in view of bringing marginal reforms. A government policy is said to be pro-poor if it benefits the poor proportionally more than the non-poor. This paper derives the poverty elasticity for the general class of poverty. Using the idea of poverty elasticity, this paper proposes a pro-poor index that can be utilized to assess government expenditure and tax policies. This index may be useful in making the government fiscal system more beneficial for the poor through marginal reforms. The proposed methodology is applied to Thailand, utilizing the 1998 Socio-Economic Survey.

The structure of the paper is as follows: section 2 provides the basic framework of the methodology proposed in the paper; section 3 describes the overall fiscal system in Thailand; sction 4 provides a description of the data source used for the study and also analyzes empirical results; and section 5 contains the conclusion of the paper.

\section{METHODOLOGY}

\subsection{POVERTY MEASURES}

Suppose income $x$ of an individual is a random variable with a distribution function given by $F(x)$. Let $z$ be the poverty line, then $H=F(z)$ is the proportion of individuals whose income falls below the poverty line or $H$ is the proportion of poor in the society. $H$ is the most popularly used poverty measure and is called the head-count ratio.

The head-count ratio is a crude measure of poverty. The percentage of the population that is poor does not reflect the intensity of poverty suffered by the poor. A suitable measure of poverty should take into account the three indicators of poverty, which include the percentage of poor, the aggregate poverty gap, and the distribution of income among the poor.

A general class of a poverty measure that combines these three characteristics of poverty can be written as

$$
\theta=\int_{0}^{z} P(z, x) f(x) d x
$$


where $f(x)$ is the density function of $x$ and

$$
\frac{\partial \mathrm{P}}{\partial \mathrm{x}}<0, \frac{\partial^{2} \mathrm{P}}{\partial \mathrm{x}^{2}}>0, \mathrm{P}(\mathrm{z}, \mathrm{z})=0
$$

and $P(z, x)$ is a homogenous function of degree zero in $z$ and $x$. Foster, Greer and Thorbecke's (1984) class of poverty measures is obtained when we substitute $P(z, x)=\left(\frac{z-x}{z}\right)^{\alpha}$ in (1) to get

$$
\theta_{\alpha}=\int_{0}^{z}\left(\frac{z-x}{z}\right)^{\alpha} f(x) d x
$$

where $\alpha$ is the parameter of inequality aversion. For $\alpha=0, \theta_{0}=H$, the head-count measure. This measure gives equal weight to all poor, irrespective of the intensity of their poverty. For $\alpha=1$, each poor person is weighed by his or her distance from the poverty line, relative to $z$. This measure is called the poverty gap ratio. For $\alpha=2$, the weight given to each poor person is proportional to the square of the income shortfall of the poor person from the poverty line. This measure is called the severity of poverty measure and takes all three poverty characteristics mentioned above into account.

\subsection{GROWTH ELASTICITY OF POVERTY}

A poverty measure can be written as

$$
\theta=\theta(z, \mu, L(p))
$$

where $\mu$ is the mean income of the society and $L(p)$ is the Lorenz function, measuring the relative income distribution. $L(p)$ is the percentage of income that is enjoyed by the bottom $p$ percent of the population.

The growth elasticity of poverty measures the effect of a change in $\mu$ on $\theta$ when $L(p)$ remains constant. This elasticity, derived by Kakwani (1993), is given by

$$
\eta_{\theta}=\frac{1}{\theta} \int_{0}^{z} x \frac{\partial P}{\partial x} f(x) d x
$$

which is always negative in view of $\frac{\partial P}{\partial x}<0$. For the head-count measure, $P(z, x)=1$, the elasticity is derived as

$$
\eta_{H}=-\frac{z f(z)}{H}<0
$$


which is the percentage of poor who will cross the poverty line as a result of 1 percent of growth in the mean income of the society.

Substituting $P(z, x)=\left(\frac{z-x}{z}\right)^{\alpha}$ into (4) gives the elasticity of $\theta_{\alpha}$ with respect to $\mu$ as

$$
\eta_{\alpha}=\frac{\partial \theta_{\alpha}}{\partial \mu} \frac{\mu}{\theta_{\alpha}}=-\frac{\alpha\left(\theta_{\alpha-1}-\theta_{\alpha}\right)}{\theta_{\alpha}}
$$

for $\alpha \neq 0$, which will always be negative because $\theta_{\alpha}$ is a monotonically decreasing function of $\alpha$.

\subsection{GROWTH ELASTICITY OF INCOME COMPONENTS}

The total (or net) income of an individual is the sum of several income components, which consists of market income (e.g. wages and salary, interest, and investment income) and income from self-employment and non-market income (e.g. various government transfers such as old-age pension, family allowance, disability pension, and unemployment benefits). Since poverty should be measured on the basis of disposable income (the income available to individuals), we must deduct personal income tax paid by the individuals from the gross income. Let $\mathrm{x}$ be the net or disposable income and $g_{i}(x)$ the ith income component received by an individual or household with net income $x$. Then,

$$
x=\sum_{i=1}^{m} g_{i}(x)
$$

where $m$ is the total number of income components, one of which is the income tax paid by the individual and which enters in (6) as a negative component. Following Kakwani (1980), the concentration function of the ith income component (or $C_{i}(p)$ ) is defined as the percentage of the ith income component enjoyed by the bottom $p$ percent of the population.

The first derivative of $C_{i}(p)$ with respect to $\mathrm{p}$ is given by $C_{i}^{\prime}(p)=\frac{g_{i}(x)}{\mu_{i}}$, where $\mu_{\mathrm{i}}$ is the mean of the ith income component. Substituting in (6) gives

$$
x=\sum_{i=1}^{n} \mu_{i} C_{i}^{\prime}(p)
$$

Our objective is to measure the responsiveness of $\theta$ with respect to the mean of the ith income component, $\mu_{\mathrm{i}}$. This is accomplished by deriving the elasticity of $\theta$ with respect to $\mu_{\mathrm{i}}$, which we may call the ith income component elasticity. To derive this elasticity, we assume that a change in $\mu_{\mathrm{i}}$ does not affect the distribution of the ith income component across the net income. The concentration function $C_{i}(p)$ measures the distribution of the ith income component across the total (net) income. In the derivation of the income component elasticity, we therefore assume that $C_{i}(p)$ does not change when $\mu_{i}$ changes. Thus, differentiating (7) with respect to $\mu_{i}$ when keeping $C_{i}^{\prime}(\mathrm{p})$ constant gives

$$
\mu_{i} \frac{\partial x}{\partial \mu_{i}}=\mu_{i} C_{i}^{\prime}(p)=g_{i}(x)
$$


Differentiating (1) and using (8) gives the elasticity of $\theta$ with respect to $\mu_{i}$ as

$$
\eta_{\theta i}=\frac{\partial \theta}{\partial \mu_{i}} \frac{\mu_{i}}{\theta}=\frac{1}{\theta} \int_{0}^{z} \frac{\partial P}{\partial x} g_{i}(x) f(x) d x
$$

For the Foster, Greer and Thorbecke (1984) class of poverty measures, the ith income component elasticity is derived from (8) as

$$
\eta_{\alpha i}=-\frac{\alpha}{\theta_{\alpha}} \int_{0}^{z} \frac{1}{z}\left(\frac{z-x}{z}\right)^{\alpha-1} g_{i}(x) f(x) d x
$$

for $\alpha \neq 0$, which can easily be computed given data on income components and the net income $x$. The mean income component elasticity for the head-count ratio is given by

$$
\eta_{H i}=\frac{\partial H}{\partial \mu_{i}} \frac{\mu_{i}}{H}=-\frac{g_{i}(z) f(z)}{H},
$$

where $g_{i}(z)$ is the value of the ith income component when an individual has an income equal to the poverty line.

\subsection{PRO-POOR INDEX OF THE INCOME COMPONENTS}

The income components provide the information about the components of a fiscal system. From a policy point of view, it is important to know to what degree a particular income component is pro-poor or anti-poor. In this section, we derive a pro-poor index for the ith income component.

In view of (4), (6) and (9), it can easily be seen that

$$
\sum_{i=1}^{m} \eta_{\theta i}=\eta_{\theta}
$$

which implies that if all income components grow at the same rate of 1 percent, then the total poverty will change by $\eta_{\theta}$ percent.

When $\mu_{i}$ changes, it has two effects. First, $\mu_{i}$ changes the mean income $\mu$ and second, $\mu_{i}$ shifts the Lorenz curve. To see the effect of a change in $\mu_{i}$ on the Lorenz curve, we follow Kakwani (1980) and write

$$
L(p)=\sum_{i=1}^{m} \frac{\mu_{i}}{\mu} C_{i}(p)
$$

which, on differentiating with respect to $\mu_{i}$, gives

$$
\frac{\partial L(p)}{\partial \mu_{i}} \frac{\mu_{i}}{L(p)}=\frac{\mu_{i}}{\mu} \frac{\left[C_{i}(p)-L(p)\right]}{L(p)}
$$


This expression defines the elasticity of $L(p)$ with respect to $\mu_{i}$. This equation shows that if $C_{i}(p)>L(p)$ for all $\mathrm{p}$, the Lorenz curve will shift upward as a result of an increase in $\mu_{i}$. This will have the effect of reducing poverty. When the Lorenz curve shifts downward (which occurs when $\mathrm{C}_{\mathrm{i}}(\mathrm{p})<\mathrm{L}(\mathrm{p})$ for all $\left.\mathrm{p}\right)$, poverty increases. When the two curves $C_{i}(p)$ and $\mathrm{L}(\mathrm{p})$ cross, it is not possible to say a priori whether an increase in $\mu_{i}$ redistributes income in favor of the rich or the poor individuals. In this case, we must compute the redistribution effect of an income component on poverty. This is accomplished by decomposing the poverty elasticity $\eta_{\theta i}$ into two components:

$$
\eta_{\theta i}=\frac{\mu_{i}}{\mu} \eta_{\theta}+\left(\eta_{\theta i}-\frac{\mu_{i}}{\mu} \eta_{\theta}\right)
$$

The first term on the right-hand side is the income effect, and the second term is the redistribution effect. It is the redistribution effect that tells us whether an increase in $\mu_{i}$ favors the rich or the poor. If this component is negative (positive), it means that the redistribution effect of the ith income component reduces (increases) poverty, implying that the ith income component is pro-poor (anti-poor). This leads us to suggest a pro-poor index of the ith component as

$$
\phi_{i}=\frac{\eta_{\theta i} \mu}{\eta_{\theta} \mu_{i}}
$$

which implies that the ith component is pro-poor (anti-poor) if $\phi_{i}$ is greater (less) than 1.

$\phi_{i}$ measures the marginal benefit in terms of reducing poverty from an extra dollar spent on the ith income component. Suppose $i$ and $j$ are two different government transfer programs and if $\phi_{i}>\phi_{j}$, then one dollar spent on the ith program will lead to a greater reduction in poverty than one dollar spent on the jth program. In other words, we reduce poverty by cutting expenditure down on the jth program and increasing the expenditure of the same amount on the ith program.

\subsection{INDIRECT TAXES AND SUBSIDIES}

Indirect taxes and subsidies have direct impacts on prices. The production side of the economy is not considered here, and the incidence of taxes is assumed to be borne solely by the consumers. What would be the impact on poverty if one indirect tax were increased and another indirect tax were decreased, with the government's tax revenue unchanged? To analyze the effect of indirect taxes and subsidies at the margin, we can measure the impact of price changes (borne by indirect taxes or subsidies) on poverty. This is accomplished by deriving a poverty elasticity with respect to the prices of individual commodities. 
To derive the elasticity, let us write the demand equations of $k$ commodities as

$$
\mathbf{q}=\mathbf{q}(\mathrm{x}, \mathbf{p})
$$

where $\mathbf{p}$ and $\mathbf{q}$ are the $k \times 1$ vectors of prices and quantities of $k$ commodities, and $x$ is the disposable income. It is reasonable to assume that all individuals face the same price vector, which means that the prices are fixed across individuals. Thus, we write the demand equation as

$$
\mathbf{q}=\mathbf{q}(\mathrm{x}) \text {, }
$$

which are the quantities consumed by an individual with disposable income $x .{ }^{1}$ Utilizing these demand equations, let us write the disposable income as

$$
x=\sum_{i=1}^{k} p_{i} q_{i}(x)+S(x),
$$

where $p_{i}$ is the price of the ith commodity and $q_{i}(x)$ is the quantity of the ith commodity consumed by an individual whose disposable income is $x$, where $i=1,2, \ldots ., m . S(x)$ is the savings of the individual with income $x$.

Suppose that due to indirect taxes and subsidies, the price vector $\mathbf{p}$ changes to $\mathbf{p}^{*}$. How will this change affect the individual's real income? To answer this question, we consider the cost function $e(u, \mathbf{p})$, which is the minimum cost required to obtain $u$ level of utility when the price vector is $\mathbf{p}$. The real income of the individual with income $x$ will change by ${ }^{2}$

$$
\Delta x=-\left[e\left(u, \mathbf{p}^{*}\right)-e(u, \mathbf{p})\right],
$$

which, on using Taylor expansion, gives

$$
\Delta x=-\sum_{i=1}^{m}\left(p_{i}^{*}-p_{i}\right) q_{i}(x) .
$$

This equation immediately gives

$$
\frac{\partial x}{\partial p_{i}}=-q_{i}(x)
$$

Differentiating (1) with respect to $p_{i}$ and using (15) gives the elasticity of $\theta$ with respect to $p_{i}$ as

$$
\varepsilon_{\theta i}=\frac{\partial \theta}{\partial p_{i}} \frac{p_{i}}{\theta}=-\frac{1}{\theta} \int_{0}^{z} \frac{\partial P}{\partial x} v_{i}(x) f(x) d x,
$$

where $v_{i}(x)=p_{i} q_{i}(x)$ is the expenditure on the ith commodity. Note that this elasticity is positive because an increase in any price will increase poverty. This elasticity can be written as the sum of two components:

$$
\varepsilon_{\theta i}=-\frac{p_{i} \bar{q}_{i} \eta_{\theta}}{\mu}+\left(\varepsilon_{\theta i}+\frac{p_{i} \bar{q}_{i} \eta_{\theta}}{\mu}\right),
$$


where $\mu$ is the mean income of the disposable income and $p_{i} \overline{q_{i}}$ is the mean expenditure of the ith commodity. The first term in (17) is the income effect of the price increase, which is always positive because $\eta_{\theta}$, given in (4), is negative. The second term is the redistribution or inequality effect of price change. It is the redistribution effect that tells us whether an increase in price $p_{i}$ hurts the poor proportionally more than the non-poor. If this component is positive, it means that the increase in the price of the ith commodity hurts the poor proportionally more than the non-poor. This leads us to suggest the pro-poor price index as

$$
\varphi_{i}=-\frac{\varepsilon_{\theta i}}{s_{i} \eta_{\theta}}
$$

where $s_{i}=\frac{p_{i} \bar{q}_{i}}{\mu}$ is the expenditure on the ith commodity as a proportion of the mean income of the total disposable income. If $\varphi_{i}$ is greater (less) than 1 , an increase in the ith price hurts the poor more (less) than the non-poor. Thus, if $\varphi_{i}$ is greater than 1, then the ith commodity should be subsidized so that the poor benefit more relative to the non-poor. Similarly, if $\varphi_{i}$ is less than 1, the increase in tax on the ith commodity will hurt the non-poor more than the poor. Thus, we can use $\varphi_{i}$ as a tool to improve the tax or subsidy schemes in a way that maximizes poverty reduction.

\section{FISCAL STRUCTURE IN THAILAND}

Like many Asian countries, Thailand's fiscal system is highly centralized. The national government collects most of the taxation and also spends most of it. In 1998, central government revenue accounted for about 95 percent of total tax revenue and central government expenditure contributed almost 92.3 percent to total government spending (NSO 2000). It is generally believed that the centralized fiscal system contributes to the unequal distribution of public services, such as public infrastructure, education, and health.

Table 1 presents an overall revenue structure of both central and local governments. It can be seen that the major source of government revenue comes from taxation (87.61 percent). The non-tax revenue only accounts for 12.39 percent of the total revenue. The revenue share of direct taxes is 29.34 percent in Thailand. In 1998, individual income tax raised about 118,871 million baht of revenue, which amounts to 16.23 percent of the total national revenue. Like other developing countries, the share of the individual income tax in the total national tax revenue is small. Given the view that the revenue composition of the tax system reflects both structural and cyclical economic changes, it is also useful to note that the year of 1998 was a period of financial crisis, in which the government allowed the tax revenue to fall. The corporate income tax raised about 96,021 million baht of revenue in 1998, which was equivalent to 13.11 percent of the total government revenue. Compared with the corresponding figure in 1998, the revenue share of the corporate income tax was 8.05 percentage points higher in 2003 (NSO 2005). Thus, the revenue raising capacity of corporate income tax has increased substantially over this period. 
TABLE 1

Government revenue in Thailand 1998

\begin{tabular}{|c|c|c|}
\hline Different types of government revenue & $\begin{array}{l}\text { Actual government revenue } \\
\text { in Bhat (million) }\end{array}$ & $\begin{array}{l}\text { Distribution of } \\
\text { Revenue (\%) }\end{array}$ \\
\hline Taxes on income, profits, \& capital gains & 214,892 & 29.34 \\
\hline Payable by individuals & 118,871 & 16.23 \\
\hline Payable by corporations \& other enterprises & 96,021 & 13.11 \\
\hline Taxes on property & 5,119 & 0.70 \\
\hline Taxes on goods \& services & 352,288 & 48.10 \\
\hline $\begin{array}{l}\text { General taxes on goods \& services } \\
\text { (including value-added taxes \& sales taxes) }\end{array}$ & 196,890 & 26.88 \\
\hline Excises & 152,424 & 20.81 \\
\hline Profits of fiscal monopolies & 1,936 & 0.26 \\
\hline Taxes on specific services & 54 & 0.01 \\
\hline Taxes on use of goods, permission to use goods & 984 & 0.13 \\
\hline Taxes on international trade \& transactions & 66,090 & 9.02 \\
\hline Customs \& other import duties & 66,069 & 9.02 \\
\hline Taxes on exports & 21 & 0.00 \\
\hline Other taxes & 3,189 & 0.44 \\
\hline Total Tax revenue & 641,578 & 87.61 \\
\hline Grants from foreign governments & 4,485 & 0.61 \\
\hline Other revenue & 86,288 & 11.78 \\
\hline Property income & 58,086 & 7.93 \\
\hline Sales of goods and services & 8,321 & 1.14 \\
\hline Fines, penalties, and forfeits & 7,923 & 1.08 \\
\hline Voluntary transfers other than grants & NA & NA \\
\hline Miscellaneous and unidentified revenue & 11,958 & 1.63 \\
\hline Total Non-tax revenue & 90,773 & 12.39 \\
\hline Total revenue & 732,351 & 100.00 \\
\hline
\end{tabular}

Source: Author's calculations based on the data provided by the Ministry of Finance.

Note: NA = Not Applicable.

In Thailand, the tax revenue is mainly collected from indirect taxes, which accounted for almost 57 percent of total tax revenue in 1998. Within the indirect tax structure, two broadlydefined taxes dominate. These are general taxes on goods and services (which include Value Added Tax (VAT) and sales taxes) and excise taxes. The most dominant indirect taxes are the VAT and other sales taxes, which account for almost 27 percent of the total government revenue. VAT is a sales tax levied on producers and importers of goods and services based on their gross sale receipts or import values. While VAT was introduced in Thailand in 1992, it has been an important source for government tax revenue (NSO 2000). The excise or selective sales taxes in Thailand are levied on items, such as tobacco and liquor, automobiles, and petroleum products. The contribution of these taxes to total revenue accounts for 20.81 percent. 
On the whole, Thailand depends largely on indirect taxes for its revenue. This suggests that the incidence of the indirect tax burden plays a large role in determining the pro-poorness of the overall tax burden in the country. Therefore, the government, to achieve its objective of improving the distribution of income, needs to rely less on the indirect taxes in general and the VAT in particular, and move toward greater reliance on direct taxes.

In 1998, total government revenue as the percentage of gross domestic product (GDP) in Thailand was 16.2 percent, while the government expenditure was 23.8 percent of GDP (NSO 2005). Thus, the government was running a budget deficit, which was 7.6 percent of GDP. This is a considerably large budget deficit as the economy in 1998 was hit by a financial crisis. The budget deficit further increased to 11.2 percent of GDP in 1999 but dramatically declined in subsequent years to 3.2 and 2.0 percent of GDP in 2000 and 2001, respectively.

TABLE 2

\section{Government expenditure by functional classification}

\begin{tabular}{lcc}
\hline Expenditure by Function & $\begin{array}{c}\text { Actual expenditure } \\
\text { in Bhat (million) }\end{array}$ & $\begin{array}{c}\text { Distribution of } \\
\text { expenditure }\end{array}$ \\
\hline General public services & 105,817 & 10.2 \\
Defense affairs \& services & 88,327 & 8.5 \\
Public order and safety & 52,281 & 5.1 \\
Housing and community amenities & 40,612 & 3.9 \\
Health affairs \& services & 70,129 & 6.8 \\
Education affairs \& services & 196,411 & 19.0 \\
Social security \& welfare & 32,880 & 3.2 \\
Recreation, culture and religion & 13,459 & 1.3 \\
Agriculture, forestry, \& fishery affairs & 59,571 & 5.8 \\
Fuel \& energy & 2,531 & 0.2 \\
Mining, manufacturing, \& construction & 4,261 & 0.4 \\
Transport \& communication & 135,803 & 13.1 \\
Other economic services & 232,964 & 22.5 \\
\hline Total Government expenditure & & 100.0 \\
\hline
\end{tabular}

Source: Author's calculations based on the data provided by the Ministry of Finance.

Table 2 presents the structure of Thai government expenditures classified by functions. Of the four major functions - economic services, social services, defense, and general public services - economic services rank first among the four in terms of the share of the total expenditure. Almost 42 percent of the budget is allocated to this item, which includes spending on agricultural and natural resources, transportation and communication, commerce and industry, and other economic development activities. The second biggest item of government expenditure is social services that include health, education, social security and welfare, and cultural activities. As a whole, its share makes up 34.2 percent of total expenditure. A further breakdown of social services shows that high priority is given to education affairs and services, which accounts for 19 percent of total public expenditure. Compared to education, a small share of the budget is devoted to health services. Its share of total expenditure is 6.8 percent. 


\section{DATA ANALYSIS}

\subsection{DATA SOURCE}

The data source comes from the Socio-Economic Surveys (SES) conducted in 1998. The SES data are unit record household surveys conducted every two years by the National Statistics Office in Thailand. The survey is nationwide and covers all private, non-institutional households residing permanently in municipal, sanitary districts, and villages. However, it excludes part of the population living in transient hotels or rooming houses, boarding schools, military barracks, temples, hospitals, prisons and other such institutions. The 1998 SES contains detailed information on income and consumption components for 86,058 individuals living in 23,548 households.

As an indicator of individual welfare, this study has chosen per capita income. For this study, the concept of income should be comprehensive enough to include all of the components which have impacts on people's welfare. The definition of income used in the study includes the following sources:

- wages and salaries

- entrepreneurial income

- farm income

- rent from roomers and boarders, land rent for farming, and other non-farming rent, and royalties

- interest and dividends

- assistance and remittance

- pensions and annuities

- terminal pay and other transfers

- food, rent, and other goods as part of pay

- home produced food

- imputed rent of owner-occupied home

- other home-produced goods

- crops received as rent

- food, rent, and other goods received free

Since taxes people pay do not make a direct contribution to their welfare, this study uses the concept of disposable income, obtained from subtracting direct taxes from total current income.

The economic welfare of households is determined not only by their income, but also by their needs. Since households differ in size, age composition, and other characteristics, it is expected that they will have different needs. In a recent study, Kakwani (2003) developed poverty thresholds, which take the different needs of people living in households into account. ${ }^{3}$ The study uses these poverty lines to calculate the pro-poorness of the fiscal system in Thailand. 


\subsection{ANALYSIS OF EMPIRICAL RESULTS}

Table 3 presents the values of poverty elasticity and the pro-poor index for different income components. Public policies can be assessed for different measures of poverty. The head-count ratio is a crude measure of poverty because it completely ignores the gap in incomes from the poverty line and the distribution of income among the poor. The severity of the poverty index has all the desirable properties. As such, this study only focuses on two poverty measures: poverty gap and the severity of poverty measure. Compared to the poverty gap ratio, the severity of poverty index gives a greater weight to poorer individuals in the society. If our concern were specifically with the ultra-poor, then we would choose the severity of poverty rather than the poverty gap ratio.

TABLE 3

\section{Pro-Poor Index for income components}

\begin{tabular}{|c|c|c|c|c|c|}
\hline \multirow{2}{*}{ Income components } & \multirow{2}{*}{$\begin{array}{l}\text { Percent } \\
\text { Share }\end{array}$} & \multicolumn{2}{|c|}{ Poverty gap ratio } & \multicolumn{2}{|c|}{ Severity of poverty } \\
\hline & & $\begin{array}{l}\text { Poverty } \\
\text { Elasticity }\end{array}$ & Pro-Poor index & $\begin{array}{l}\text { Poverty } \\
\text { Elasticity }\end{array}$ & Pro-Poor index \\
\hline Wage and salary & 42.1 & -0.684 & 0.60 & -0.707 & 0.57 \\
\hline Entrepreneurial income & 19.2 & -0.190 & 0.36 & -0.184 & 0.32 \\
\hline Farm income & 10.8 & -0.449 & 1.54 & -0.482 & 1.52 \\
\hline Rent from boarders & 0.6 & -0.001 & 0.05 & -0.001 & 0.06 \\
\hline Land rent from farming & 0.2 & -0.003 & 0.64 & -0.003 & 0.66 \\
\hline Other rent from non-farming & 0.1 & -0.003 & 1.54 & -0.002 & 0.66 \\
\hline Interest and dividends & 1.1 & -0.005 & 0.16 & -0.006 & 0.19 \\
\hline Remittances & 6.5 & -0.182 & 1.03 & -0.186 & 0.97 \\
\hline Pensions and annuities & 1.3 & -0.001 & 0.02 & -0.000 & 0.01 \\
\hline Terminal pay and others & 0.1 & -0.001 & 0.28 & -0.001 & 0.20 \\
\hline Food as part of pay & 0.4 & -0.005 & 0.48 & -0.005 & 0.41 \\
\hline Rent received as pay & 0.6 & -0.006 & 0.34 & -0.006 & 0.32 \\
\hline Other goods as pay & 0.8 & -0.004 & 0.19 & -0.003 & 0.11 \\
\hline Home produced food & 4.0 & -0.506 & 4.71 & -0.575 & 4.93 \\
\hline Owner occupied home & 9.8 & -0.494 & 1.86 & -0.587 & 2.04 \\
\hline Other home goods & 0.6 & -0.065 & 4.13 & -0.080 & 4.64 \\
\hline Crops received as rent & 0.1 & -0.003 & 0.94 & -0.001 & 0.40 \\
\hline Food received free & 1.0 & -0.055 & 2.12 & -0.059 & 2.08 \\
\hline Rent received free & 0.5 & -0.013 & 1.05 & -0.016 & 1.21 \\
\hline Other goods free & 1.0 & -0.044 & 1.64 & -0.051 & 1.74 \\
\hline Total money income & 82.0 & -1.519 & 0.68 & -1.572 & 0.65 \\
\hline Total in-kind income & 18.6 & -1.194 & 2.36 & -1.382 & 2.51 \\
\hline Taxes & -0.6 & 0.001 & 0.08 & 0.001 & 0.07 \\
\hline Income tax & -0.60 & 0.001 & 0.04 & 0.001 & 0.08 \\
\hline House and land tax & -0.02 & 0.001 & 1.18 & 0.000 & 0.76 \\
\hline Fine rate & -0.00 & 0.000 & 0.63 & 0.000 & 0.58 \\
\hline Other taxes & -0.00 & 0.000 & 0.03 & 0.000 & 0.50 \\
\hline Total current disposable income & 100.0 & -2.71 & 1.00 & -2.95 & 1.00 \\
\hline
\end{tabular}

Source: author's calculations based on the 1998 SES. 
FIGURE 1

Pro-Poor index for income components, poverty gap ratio

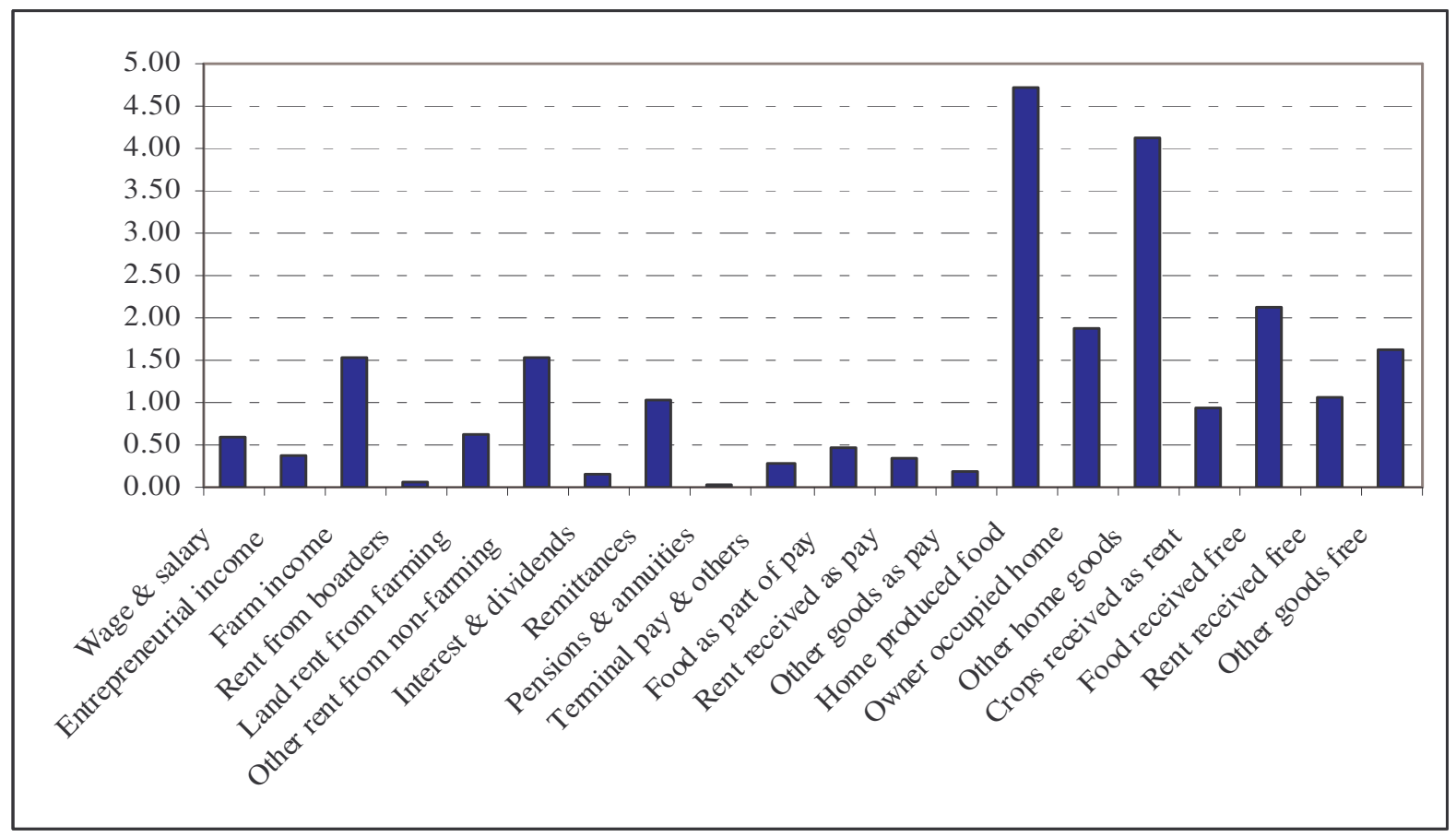

As can be seen from the results in the table, the poverty elasticity varies widely for different income components. As any increase in income reduces poverty, the poverty elasticities of income components take negative values. If, for instance, wage and salary incomes increase by 1 percent, poverty measured by the poverty gap and severity of poverty will fall by 0.684 and 0.707 percent, respectively. Thus, the percentage of reduction in poverty is greater for any increase in wage and salary when the ultra-poor receive a greater weight than the poor.

As pointed out earlier, the pro-poor index can be employed to make government fiscal policy more pro-poor in a way that benefits the poor proportionally more than the non-poor. An income component is said to be pro-poor (anti-poor) if the pro-poor index is greater (less) than unity. The higher the value of the index, the greater will be the proportional benefits accrued to the poor. For example, the pro-poor index has the highest value of 4.71 for homeproduced goods, which means that any subsidy given to households whose main income is generated from home-produced goods will help the poor much more than the non-poor. Similar results emerge for income components such as other home produced goods, free in-kind income, imputed rent from owner occupied homes, and farming income.

It is generally believed that the major source of income of the poor is wage and salary. This may lead to a belief that any policy that increases wage and salary income will be propoor. However, this proposition is not substantiated by empirical results. The pro-poor index for the wage and salary income is 0.60 for the poverty gap ratio, implying that any increase in wage and salary will benefit the non-poor proportionally more than the poor. Other income components that do not favor the poor include entrepreneurial income, rent from property, interest and dividends, pensions and annuities, and so forth. 
The SES data record only the direct taxes that are collected by the households. The propoor index of the tax as a whole is only 0.08 for the poverty gap ratio. This suggests that the direct taxes are largely paid by the non-poor, which have almost negligible impacts on poverty as indicated by the pro-poor index. The pro-poor index for the personal income tax is 0.04 , implying that this tax is largely paid by the non-poor and thus highly pro-poor.

As noted in section 3, the government collected 13.11 percent of its revenue from corporate taxes. This tax component has increased rapidly over time in Thailand. Its share in 2003 was equivalent to 22 percent of its total revenue. In an open economy such as Thailand, it is reasonable to assume that the burden of corporate taxes is mostly borne by wage and salary earners. The pro-poor index for wage and salary income is 0.60 for the poverty gap ratio, suggesting that any tax burden borne by wage and salary earners will fall on the non-poor. Given the magnitude, corporate tax can be said to be pro-poor, but its degree of pro-poorness is much smaller than that of personal income tax.

Surprisingly, the pro-poor index for house and land tax is 1.18. This means that the poor pay proportionally more of these taxes than the non-poor. In 1998, the government was able to collect only 0.70 percent of its revenue from house and land taxes. As the share of this tax is fairly small, it will have little impact on poverty even if it is pro-poor. This finding suggests that there is a scope for the government to improve or redesign the house and land tax in a way that the non-poor pay proportionally more than the poor.

Pensions and annuities contribute 1.3 percent to total personal income. These income sources are found to be highly anti-poor, as indicated by the value of the pro-poor index, equivalent to 0.02 for the poverty gap ratio. This suggests that the poor do not have access to any pensions and annuities, which are mainly given to retired public servants. The Thai government does not have a welfare assistance programme that is specifically designed to help vulnerable groups such as the poor. Instead, there is a form of informal safety nets provided by family members. Informal safety nets can take the form of domestic and overseas remittances. As presented in Table 3, the remittances contribute around 6.5 percent to the disposable income with its value of pro-poor index equal to 1.03 for the poverty gap ratio. Thus, remittances are indeed pro-poor, benefiting the poor proportionally more than the nonpoor. However, the index falls to 0.97 when it is calculated for the severity of poverty measure: the ultra-poor get less of a proportion of the remittances than the poor.

Table 4 presents the values of poverty elasticity with respect to prices. Since increases in prices reduce people's real income and thus increase poverty, the elasticities all take positive values. Values of the pro-poor index can be either greater or less than one. The larger (smaller) value of the pro-poor index than unity suggests that the increase in prices would hurt the poor more (less) than the non-poor. For instance, the index is highly anti-poor for grains and cereal products: its index value is 4.43 for the poverty gap ratio and further increases to 5.07 for the severity of poverty. This indicates that subsidizing these items will benefit the poor much more than the non-poor. A similar conclusion emerges from other food items. These findings point to the view that indirect taxes on food items are likely to be anti-poor. For this reason, to partially correct the anti-poorness of the indirect tax burden, basic necessities such as unprocessed foodstuffs, medical and health services, and educational materials should be exempted from the VAT.

By comparison, the value of the pro-poor index for alcoholic beverages consumed outside the home is shown to be less than one: 0.80 and 0.81 for the poverty gap and severity of 
poverty, respectively. This suggests that any indirect tax on alcoholic beverages consumed outside the home will have less adverse impact on the poor than on the non-poor. This conclusion, however, becomes invalid if our focus is on the alcohol beverages consumed at home. Its pro-poor index rises to 1.59, suggesting that any tax on alcohol consumed at home is likely to hurt the poor proportionally more than the non-poor. To achieve the maximum reduction in poverty, therefore, alcohol can be taxed more heavily when it is sold and consumed at bars or restaurants.

Government often allows a variety of exemptions for social, political, and administrative reasons in applying the indirect taxes such as VAT. Exemptions may be awarded to the supply of basic necessities and services (e.g. unprocessed food), social welfare services such as medical and health services, goods or services related to culture (e.g. education, books, newspapers, and artistic works), and so forth. In this regard, the results show that tax exemptions or subsidies on education and health would benefit the poor (particularly the ultra-poor) more than the non-poor.

The Thai government plays an important role in providing educational services to the people. Nevertheless, the pro-poor index for the private expenditure on education indicates that the poor tend to pay proportionally much more than the non-poor. This finding is suggested by the pro-poor index, which is equal to 2.16 for the poverty gap. The index is increased to 2.55 when our focus is on the severity of poverty measure. This suggests that ultra-poor people pay proportionally more than poor ones. Within the educational expenses, the study has calculated the pro-poor indices for detailed items which are shown in Table 4. The results show that the burden of the price increase, which may stem from the VAT, in items such as text books, school equipment, or public primary and secondary school fees will be borne more by the poor rather than by the non-poor. On the other hand, price curtails in tuition fees for private vocational institutes and both private and public universities, which may stem from the government educational subsidies, will benefit students from non-poor households proportionally more than those from poor ones.

When we look at the private expenditure on health, a similar story emerges. The pro-poor index for private expenditure on medicine and medical services takes a value far greater than one, suggesting that the poor will bear proportionally more burden than the non-poor from the price increase in these health services. More specifically, a price rise in some medicines (e.g. cough remedies) will have a more detrimental effect on the poor compared to other medicines (e.g. traditional and herbal drugs or first aid kits). Similarly, government subsidies given to certain medical services (e.g. X-ray and laboratory fees) will be more beneficial to the poor relative to other medical services (e.g. private hospitals and health centres for outpatients). As the health services in Thailand are, in general, provided based on a user-principle, the poor are likely to bear a proportionally greater burden from the price increases in these services compared to the non-poor.

Overall, the value of the pro-poor index indicates that the incidence of the indirect tax burden will be borne by the poor rather than by the non-poor. The ultra-poor will be even more adversely affected by the increase in the indirect tax, which is suggested by the index value of 2.46 for the severity of poverty. In this connection, a number of empirical studies have found that indirect taxes are proportional to income or even somewhat inversely related to income (Heller 1981, Oh 1982). It is also found that while the incidence of the special excise tax burden is estimated to be significantly less adverse to the poor compared with the VAT, it may 
not really be improving income distribution. Although excise taxes on items such as liquor and tobacco levy higher rates on the higher quality products consumed by the middle- and upperincome class, the average tax amount tends to rise less than proportionately as income rises. This ensures a greater tax burden on the poor. In general, the VAT is considered to be regressive as lower income taxpayers consume a higher proportion of their income than do middle- and upper-income taxpayers. This suggests that the incidence of the VAT burden on food items and other essential commodities is likely to be borne by poor people rather than by the non-poor ones. This has been supported by our empirical results.

TABLE 4

\section{Pro-Poor Index for consumption expenditure components}

\begin{tabular}{|c|c|c|c|c|c|}
\hline \multirow{2}{*}{ Expenditure items } & \multirow{2}{*}{$\begin{array}{l}\text { Percent } \\
\text { Share }\end{array}$} & \multicolumn{2}{|c|}{ Poverty gap ratio } & \multicolumn{2}{|c|}{ Severity of poverty } \\
\hline & & $\begin{array}{l}\text { Poverty } \\
\text { Elasticity }\end{array}$ & $\begin{array}{l}\text { Pro-Poor } \\
\text { index }\end{array}$ & $\begin{array}{l}\text { Poverty } \\
\text { Elasticity }\end{array}$ & $\begin{array}{l}\text { Pro-Poor } \\
\text { index }\end{array}$ \\
\hline Grains \& cereal products & 4.95 & 0.595 & 4.43 & 0.741 & 5.07 \\
\hline Meat \& poultry & 3.46 & 0.307 & 3.28 & 0.384 & 3.77 \\
\hline Fish \& seafood & 2.80 & 0.284 & 3.74 & 0.366 & 4.44 \\
\hline Milk, cheese \& eggs & 1.95 & 0.136 & 2.57 & 0.166 & 2.89 \\
\hline Oils \& fats & 0.48 & 0.048 & 3.70 & 0.064 & 4.56 \\
\hline Fruits \& nuts & 1.72 & 0.079 & 1.69 & 0.103 & 2.04 \\
\hline Vegetables & 2.49 & 0.249 & 3.68 & 0.310 & 4.22 \\
\hline Sugar \& sweets & 0.71 & 0.062 & 3.23 & 0.089 & 4.23 \\
\hline Spices, coffees \& teas & 0.91 & 0.068 & 2.75 & 0.091 & 3.41 \\
\hline Prepared meals taken home & 3.30 & 0.148 & 1.65 & 0.184 & 1.89 \\
\hline Non-alcoholic beverages at home & 0.66 & 0.024 & 1.31 & 0.032 & 1.64 \\
\hline Alcoholic beverages at home & 0.80 & 0.035 & 1.59 & 0.041 & 1.74 \\
\hline Alcoholic beverages drunk outside & 0.45 & 0.010 & 0.81 & 0.011 & 0.82 \\
\hline Meals eaten away from home & 5.97 & 0.194 & 1.20 & 0.259 & 1.47 \\
\hline Tobacco products & 0.98 & 0.054 & 2.02 & 0.070 & 2.40 \\
\hline Clothing & 2.35 & 0.116 & 1.83 & 0.148 & 2.15 \\
\hline Footwear & 0.58 & 0.037 & 2.31 & 0.047 & 2.74 \\
\hline Shelter & 13.07 & 0.575 & 1.62 & 0.698 & 1.81 \\
\hline Fuel \& light & 3.64 & 0.222 & 2.25 & 0.277 & 2.58 \\
\hline Textile house furnishings & 0.20 & 0.013 & 2.46 & 0.018 & 3.19 \\
\hline Minor house equipment & 0.12 & 0.006 & 2.05 & 0.009 & 2.59 \\
\hline Major house equipment & 0.24 & 0.009 & 1.32 & 0.012 & 1.76 \\
\hline Cleaning supplies & 0.91 & 0.053 & 2.16 & 0.070 & 2.61 \\
\hline Servants & 0.19 & 0.000 & 0.03 & 0.000 & 0.01 \\
\hline Personal care items & 1.58 & 0.103 & 2.40 & 0.132 & 2.83 \\
\hline Personal services & 0.41 & 0.020 & 1.80 & 0.026 & 2.11 \\
\hline Local transportation & 1.52 & 0.062 & 1.49 & 0.084 & 1.86 \\
\hline Travel out of area & 0.64 & 0.018 & 1.06 & 0.029 & 1.55 \\
\hline Vehicle operation & 4.75 & 0.194 & 1.51 & 0.247 & 1.76 \\
\hline Vehicle purchase & 2.82 & 0.084 & 1.09 & 0.107 & 1.28 \\
\hline Communication services & 1.56 & 0.017 & 0.41 & 0.021 & 0.46 \\
\hline
\end{tabular}




\begin{tabular}{|c|c|c|c|c|c|}
\hline \multirow{2}{*}{ Expenditure items } & \multirow{2}{*}{$\begin{array}{l}\text { Percent } \\
\text { Share }\end{array}$} & \multicolumn{2}{|c|}{ Poverty gap ratio } & \multicolumn{2}{|c|}{ Severity of poverty } \\
\hline & & $\begin{array}{l}\text { Poverty } \\
\text { Elasticity }\end{array}$ & $\begin{array}{l}\text { Pro-Poor } \\
\text { index }\end{array}$ & $\begin{array}{l}\text { Poverty } \\
\text { Elasticity }\end{array}$ & $\begin{array}{l}\text { Pro-Poor } \\
\text { index }\end{array}$ \\
\hline Communication equipment & 0.05 & 0.000 & 0.30 & 0.000 & 0.23 \\
\hline Admissions & 0.12 & 0.002 & 0.56 & 0.003 & 0.83 \\
\hline Recreation \& sport equipment & 0.42 & 0.007 & 0.63 & 0.009 & 0.70 \\
\hline Musical equipment & 0.18 & 0.006 & 1.31 & 0.009 & 1.69 \\
\hline Reading materials & 0.24 & 0.002 & 0.33 & 0.003 & 0.47 \\
\hline Religious activities & 0.55 & 0.025 & 1.68 & 0.032 & 1.96 \\
\hline Ceremonies & 0.88 & 0.064 & 2.69 & 0.098 & 3.80 \\
\hline Miscellaneous services & 0.09 & 0.001 & 0.52 & 0.002 & 0.59 \\
\hline Education expenses & 4.04 & 0.237 & 2.16 & 0.304 & 2.55 \\
\hline Private school fees & 0.49 & 0.008 & 0.62 & 0.009 & 0.62 \\
\hline Public school fees & 0.23 & 0.017 & 2.67 & 0.022 & 3.13 \\
\hline Private vocational tuition fees & 0.20 & 0.004 & 0.73 & 0.005 & 0.75 \\
\hline Public vocational tuition fees & 0.08 & 0.004 & 1.70 & 0.006 & 2.60 \\
\hline Private university tuition fees & 0.24 & 0.003 & 0.48 & 0.001 & 0.21 \\
\hline Public university tuition fees & 0.18 & 0.002 & 0.41 & 0.003 & 0.58 \\
\hline Text books & 0.33 & 0.030 & 3.45 & 0.039 & 4.09 \\
\hline School equipment & 0.19 & 0.017 & 3.29 & 0.023 & 3.96 \\
\hline Special lessons & 0.08 & 0.001 & 0.69 & 0.001 & 0.52 \\
\hline Student lunch & 0.26 & 0.007 & 1.01 & 0.010 & 1.38 \\
\hline Pocket money & 1.74 & 0.140 & 2.97 & 0.182 & 3.55 \\
\hline Other education expenses & 0.02 & 0.003 & 3.89 & 0.003 & 4.31 \\
\hline Medicine & 0.39 & 0.028 & 2.68 & 0.036 & 3.16 \\
\hline Cough remedies & 0.03 & 0.003 & 4.41 & 0.004 & 5.38 \\
\hline Antipyretics \& Analgesics & 0.09 & 0.009 & 3.73 & 0.012 & 4.34 \\
\hline Cold remedies & 0.03 & 0.002 & 2.73 & 0.003 & 3.27 \\
\hline Anti-inflammatory analgesics & 0.03 & 0.003 & 3.53 & 0.004 & 4.30 \\
\hline Antimicrobials & 0.01 & 0.001 & 3.43 & 0.001 & 3.58 \\
\hline Anti venom & 0.01 & 0.000 & 2.62 & 0.000 & 2.96 \\
\hline Anti fungal & 0.01 & 0.000 & 1.79 & 0.000 & 2.06 \\
\hline Antiseptics & 0.00 & 0.000 & 2.15 & 0.000 & 3.03 \\
\hline Laxatives & 0.00 & 0.000 & 2.59 & 0.000 & 2.29 \\
\hline Anthelmintics & 0.00 & 0.000 & 4.33 & 0.000 & 5.72 \\
\hline Antacids \& digestives & 0.02 & 0.001 & 2.43 & 0.001 & 2.62 \\
\hline Anti diarrheas & 0.01 & 0.001 & 3.19 & 0.001 & 3.81 \\
\hline Contraceptives & 0.02 & 0.001 & 3.02 & 0.002 & 3.50 \\
\hline Inhalants & 0.00 & 0.000 & 2.18 & 0.000 & 2.80 \\
\hline Vitamins & 0.02 & 0.001 & 1.45 & 0.001 & 1.94 \\
\hline Other modern drugs & 0.06 & 0.003 & 1.74 & 0.004 & 2.07 \\
\hline Traditional \& herbal drugs & 0.05 & 0.001 & 1.03 & 0.002 & 1.36 \\
\hline First aid kits & 0.01 & 0.000 & 1.67 & 0.000 & 0.88 \\
\hline
\end{tabular}




\begin{tabular}{|c|c|c|c|c|c|}
\hline \multirow{2}{*}{ Expenditure items } & \multirow{2}{*}{$\begin{array}{c}\text { Percent } \\
\text { Share }\end{array}$} & \multicolumn{2}{|c|}{ Poverty gap ratio } & \multicolumn{2}{|c|}{ Severity of poverty } \\
\hline & & $\begin{array}{c}\text { Poverty } \\
\text { Elasticity }\end{array}$ & $\begin{array}{c}\text { Pro-Poor } \\
\text { index }\end{array}$ & $\begin{array}{l}\text { Poverty } \\
\text { Elasticity }\end{array}$ & $\begin{array}{l}\text { Pro-Poor } \\
\text { index }\end{array}$ \\
\hline Medical services & 1.51 & 0.065 & 1.58 & 0.086 & 1.94 \\
\hline \multicolumn{6}{|l|}{ Outpatients } \\
\hline Government hospitals \& health centres & 0.62 & 0.028 & 1.68 & 0.036 & 1.96 \\
\hline Private hospitals \& health centres & 0.32 & 0.006 & 0.70 & 0.009 & 0.94 \\
\hline Doctor's fees & 0.02 & 0.003 & 4.19 & 0.004 & 5.38 \\
\hline Nursing fees & 0.00 & 0.000 & 3.56 & 0.000 & 1.16 \\
\hline Eye examinations \& eye glasses & 0.01 & 0.000 & 1.11 & 0.000 & 0.17 \\
\hline Dental services & 0.08 & 0.000 & 0.23 & 0.001 & 0.24 \\
\hline X-rays \& lab fees & 0.02 & 0.003 & 6.40 & 0.004 & 8.08 \\
\hline Health care cards & 0.01 & 0.001 & 2.37 & 0.001 & 2.32 \\
\hline \multicolumn{6}{|l|}{ Inpatients } \\
\hline Government hospitals \& health centres & 0.22 & 0.014 & 2.39 & 0.020 & 3.09 \\
\hline Private hospitals \& health centres & 0.19 & 0.008 & 1.48 & 0.007 & 1.21 \\
\hline Other government medical services & 0.00 & 0.000 & 3.63 & 0.000 & 1.81 \\
\hline Other private medical services & 0.01 & 0.000 & 0.61 & 0.000 & 0.07 \\
\hline Total per capita expenditure & 74.68 & 4.26 & 2.10 & 5.42 & 2.46 \\
\hline Savings & 25.32 & -1.55 & -2.26 & -2.48 & -3.32 \\
\hline
\end{tabular}

Source: author's calculation based on the 1998 SES.

FIGURE 2

\section{Pro-Poor index for prices, poverty gap ratio}

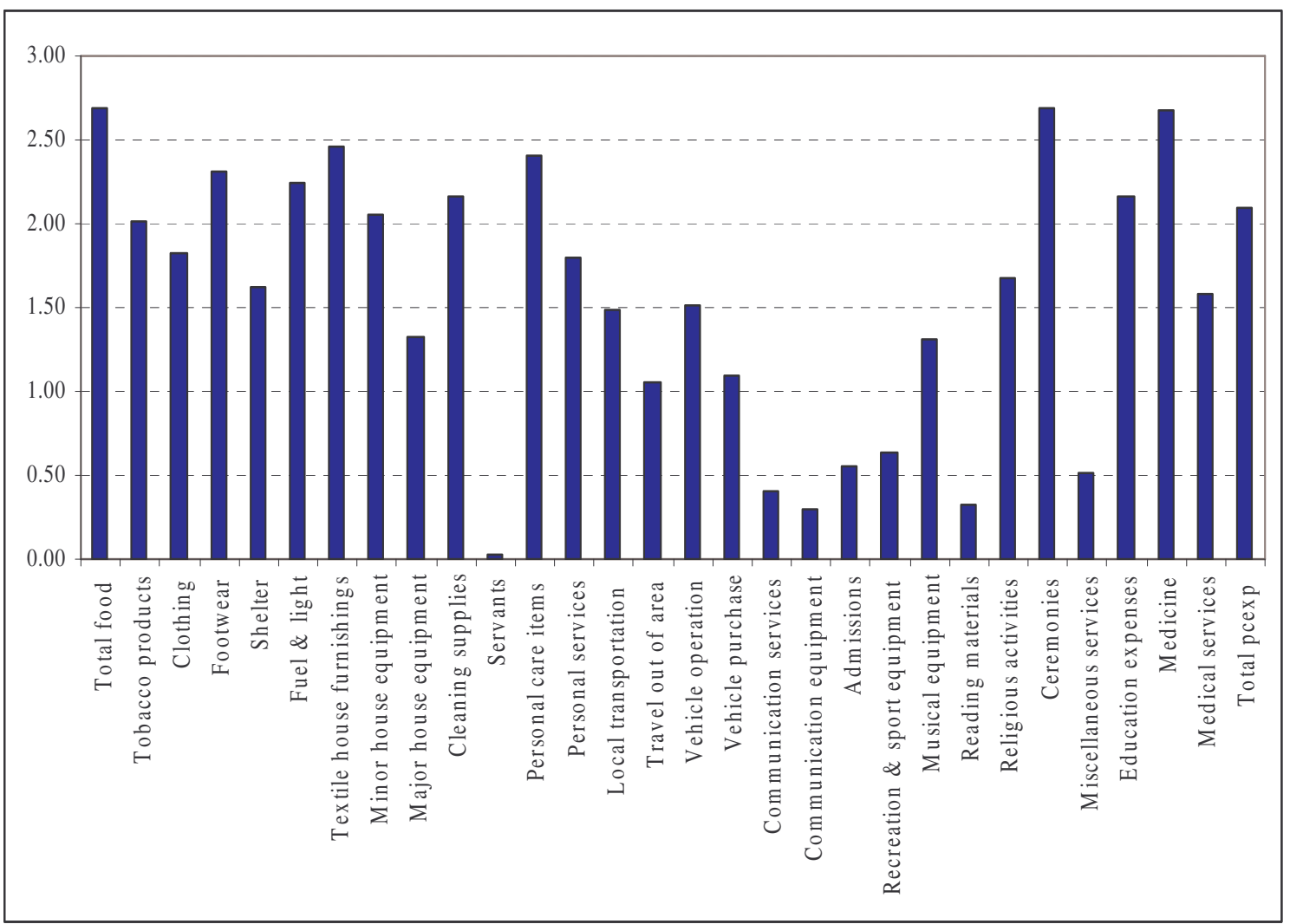


Finally, the pro-poor index reveals that savings in Thailand are highly not pro-poor. This suggests that savings are mainly done by rich people in the society. A similar result was also found by Kakwani and Son (2002). The study argues that household savings in Thailand mainly come from the top 20 percent of the population in the distribution of income, while the rest tend to dissave.

\section{CONCLUSIONS}

The inability to effectively tax personal and corporate income and wealth has obliged the Thai government to largely rely on indirect taxes, despite the common observation that heavy taxation of consumers contravenes its objectives of improving equity and reducing poverty. The central government tends to depend heavily on two indirect taxes; the VAT and the excise tax. To achieve its objectives, it is important for the government to moderate the anti-poorness of the indirect tax system in general and the VAT in particular and to move toward a greater reliance on direct taxes. Equally important, in the selection of taxable items, is the requirement for the careful consideration of the consumption patterns of the population, such as the income and price elasticities.

In this study, we attempted to evaluate the government's tax policies and public spending through investigating their marginal impacts on poverty. This task was carried out using the pro-poor index proposed in the study. The pro-poor index provides a tool to assess the impact of government public policies on poverty. The index has been derived for both prices and income components. While the pro-poor index for income components can be used to assess government expenditure policy, the index for prices can be useful in evaluating indirect taxes and subsidies. The pro-poor index was derived based on the income and price elasticities of poverty, which reflect the consumption patterns of the people in Thailand.

While the methodology proposed in the paper is able to provide some important policy implications, it also has limitations. First of all, as our analysis is carried out at the margin, in some cases it may not take into the full impacts of tax policies and public spending account. Nevertheless, the impact at the margin would provide a fairly good idea of the direction of the distributional and poverty impact of the shift, and thus be informative enough for policies. Another limitation of the study is that it does not account for either externalities stemming from public polices or any indirect effects of these policies. This limitation is largely related to the fact that they are not easy to estimate satisfactorily in practice.

When the method is applied to the 1998 Thailand household survey, the results appear to be quite intuitive. The results suggest that while the government's subsidies to in-kind incomes will benefit the poor more than the non-poor and achieve the maximum reduction in poverty, the subsidies that will incur money income will benefit the non-poor more than the poor. In addition, the marginal impact on poverty due to changes in prices through indirect taxes was studied. The empirical results showed that price increases in food items in general, through raising indirect taxes, will hurt the poor much more than the non-poor. By contrast, the price change will hurt non-poor people more than poor ones when the government increases indirect taxes on communication services and equipment, recreation, reading materials, and so forth. In addition, the results suggested that tax exemptions or subsidy schemes in education and health services overall will be pro-poor, which will lead to a greater reduction in poverty. 


\section{REFERENCES}

Foster, J., Greer, J. and Thorbecke, E. (1984). "A Class of Decomposable Poverty Measures", Econometrica 52, No.3, 761-766.

Gemmell, N. (2002). "Fiscal Policy in a Growth Framework”, Discussion Paper No. 2001/84, WIDER, Helsinki.

Heller, P.S. (1981). "Testing the impact of Value-Added and global income tax reforms on Korean Tax incidence in 1976: an input-output and sensitivity analysis", IMF Staff Papers, Vol. 23, No. 2, pp. 375-410.

Kakwani, N. (1980). Income Inequality and Poverty: Methods of Estimation and Policy Applications, Oxford University Press, New York.

Kakwani, N. (2003). "Issues in Setting Absolute Poverty Lines," Poverty and Social Development Papers No. 3/June 2003, Asian Development Bank, Manila.

Kakwani, N. and Son, Hyun, H. (2004). "Pro-Poor Growth: Asian Experience”, Working Paper No. 1, International Poverty Centre-UNDP, Brazil.

Kakwani, N. and Son, Hyun, H. (2002). "Economic Growth and Income Inequality: The Korean and Thai Experiences", In Public Policy in Asia, M. Asher, D. Newman, and T. Snyder ed. Westport: Greenwood Publishing Group.

Killick, T. (2002). "Responding to Inequality”, ERC Inequality Briefing Paper No. 3, DFID, London. National Statistical Office (2000). Yearly Statistical Book, Thailand.

National Statistical Office (2005). Yearly Statistical Book, Thailand.

McKay, A. (2002). "Assessing the Impact of Fiscal Policy on Poverty", Discussion Paper No. 2002/43, WIDER, Helsinki.

Oh, Y. C. (1982). "An evaluation of the tax reform for a Value-Added Tax in Korea with special reference to distribution of the tax burden, administrative efficiency, and export", Ph.D. Dissertation, New York: New York University. 


\section{NOTES}

1. Note that writing the demand equations in the form $q=q(x)$ does not imply that all own-price and cross-price elasticities of demand are zero. It only implies that prices do not vary across individuals.

2. $C V=\left[e\left(u, p^{*}\right)-e(u, p)\right]$ is the compensation variation, the compensation that should be given to an individual to maintain his or her utility level the same as before the price change.

3. The poverty threshold is set using the calorie requirements of individuals that differ by age and sex within the households. The poverty line also takes into account differences in costs of living between regions and areas in Thailand. Kakwani (2003) provides a good discussion on how to construct the poverty line that satisfies both consistency and specificity in the context of Thailand. 
International Poverty Centre SBS - Ed. BNDES, $10^{\circ}$ andar 70076900 Brasilia DF Brazil

povertycentre@undp-povertycentre.org www.undp.org/povertycentre

Telephone +55 6121055000

Fax +55 6121055001 